\title{
Civil War as Musical Comedy: The Representation of the Ukrainian Revolution in the Soviet Film Wedding in Malinovka (1967) $^{1}$
}

\author{
OLGA PRESSITCH \\ University of Victoria, Canada \\ olgavp@uvic.ca
}

\begin{abstract}
This article explains the continued popularity in Russia of the 1967 Soviet film Wedding in Malinovka by analyzing its reliance on the traditional Russian cultural stereotype of Ukraine embedded in the burlesque style of kotliarevshchyna. The threat that the Ukrainian Revolution historically represented to Soviet Russian identity is normalised in the film, as well as in the 1936 eponymous operetta on which it is based, by framing it as an ethnic musical sitcom with dances. Although the two main yokels of the musical hail from a long line of Ukrainian and J ewish characters of popular theatre, both are also deeply ambivalent: one is a trickster who suddenly embraces the Bolshevik cause, while the other is the funniest and least threatening villain in Soviet film.
\end{abstract}

Key words: imperial gaze, musical comedy, Russia, Soviet cinema, Ukraine, Wedding in Malinovka

\section{I ntroduction}

In April 2012 the Ukrainian right-wing Svoboda party demanded the cancellation of performances of an "anti-Ukrainian" operetta in the city of Zhytomyr by a visiting musical comedy company from St. Petersburg, Russia. ${ }^{2}$ The work that sparked such vigorous protests was Wedding in Malinovka, eminently familiar to Soviet and post-Soviet audiences in its 1967 film version. In this article I explain why the representation of Ukrainians in this musical comedy and film could be perceived as fully acceptable in the Soviet Union but deemed offensive in independent Ukraine. The notions of "imperial gaze" and ethnic stereotyping will be employed to make sense of this cultural change, but this paper must begin with an exploration of another cultural paradox: how did the light genre of a musical comedy provide a suitable vehicle for the late Soviet culture's take on the revolution in Ukraine?

\section{The J olly “Little Russians”}

In November 1967 the Soviet authorities celebrated the fiftieth anniversary of the Bolshevik Revolution with great fanfare. Today few contemporaries remember the grand parades, the political speeches, and the majestic monuments unveiled that year. Even the dozens of Soviet films on revolutionary topics released in 1967 have been completely forgotten. The best of them artistically,

\footnotetext{
${ }^{1}$ I would like to thank Henry Abramson, Serhy Yekelchyk, and the anonymous reviewers for their helpful suggestions, as well as Marta D. Olynyk, who edited the text.

2 “Zhytomyrs’ka Svoboda boikotuvala pokaz ‘antyukrainskoi’ p”iesy ‘Vesillia v Malynivtsi,’”

$<$ http://novynar.com.ua/politics/218437>, accessed 3 September 2013. 
Aleksandr Askoldov's Commissar, was banned at the time and finally released twenty years later. ${ }^{3}$ Yet, one "topical" film made that year proved an astonishing success with Soviet audiences and is still fondly remembered by many Russians today. This was the musical comedy Wedding in Malinovka. With 74.6 million tickets sold, this musical comedy became the sixth top-grossing Soviet film of all time, a close competitor of another enormously successful Soviet comedy that was released in 1967, The Female Prisoner of the Caucasus. ${ }^{4}$

There is a paradox here that I will try to explain in my paper. From the Soviet authorities' point of view, a musical comedy would not normally be the most appropriate genre in which to celebrate the Revolution's anniversary; a heroic-realist drama would be more fitting. For postwar Soviet audiences, a musical comedy had long been a favourite entertainment genre, but a revolutionary topic would normally alienate viewers. Films set abroad or in the Soviet present were usually more interesting. The unexpected success of Wedding in Malinovka represented an interesting compromise between Soviet official ideology and Russian popular taste, a compromise underwritten, as I will argue, by the imperial gaze and ethnic stereotyping.

A number of modern thinkers, most notably Michel Foucault, have employed the concept of a "gaze" to describe a relationship marked by power dynamics between the observer and the observed. Foucault emphasises the connection between observation, disciplinary mechanisms, and self-regulating mechanisms. Second-wave feminists, such as Laura Mulvey, developed the notion of the objectifying "male gaze" representing women from a male point of view, even if women themselves were culturally conditioned to share such a vision. The post-colonial theorist E. Ann Kaplan has identified a similar power relationship in what she calls the "imperial gaze," essentially the coloniser's representation of the colonised. According to her, the imperial gaze infantilises and trivialises the colonised, while at the same time asserting its dominance. Much like the women in the case of the "male gaze," the colonised are also conditioned to see themselves through an imperial lens. ${ }^{5}$ In the case of the Ukrainians in the Russian Empire and the Soviet Union, the imperial gaze was often cloaked in comedic tropes. Such a representational mode also fitted well with the genre of musical comedy that was acquiring prominence in Stalinist and later Soviet cinema.

As Richard Taylor has shown, Soviet cinema's adoption of the musical comedy genre in the 1930s was an important political decision. Supported by the head of the Soviet cinema industry, Boris Shumiatsky, the film director Grigorii Aleksandrov pioneered the Soviet take on this well-established Hollywood genre. ${ }^{6}$ If J olly Fellows (1934) and Volga, Volga (1938) were not explicitly political, in Circus (1936) and The Radiant Path (1940) Aleksandrov found a perfect combination of entertainment and propaganda. (The future director of Wedding in Malinovka, Andrei Tutyshkin, played a minor role in Volga, Volga.) Of course, these films also served as important cultural signals about what one could laugh at or sing about. The director Ivan Pyriev perfected the art of "glossing over" real social problems in the subgenre of Stalinist cinema for which he is primarily remembered, the "kolkhoz musical." His films, such as The Wealthy Bride (1938), Tractor-Drivers (1939), and The Cossacks of the Kuban (1949) portrayed the world of illusion that had little if anything to do with the Soviet peasantry's constant struggle to survive. One can argue that they illustrated better than contemporary literary works Soviet culture's embrace of what the literary scholar Katerina Clark has called "the neo-platonic element in High Stalinist epistemology."7 Such works suggested that the

\footnotetext{
${ }^{3}$ On this film, see Elena Monastireva-Ansdell, "Redressing the Commissar: Thaw Cinema Revises Soviet Structuring Myths,” Russian Review Vol. 65, No. 2, April 2006, pp. 230-49.

4 “Chempiony sovetskogo kinoprokata,” <http://multiplex.ua/Page.aspx?id=366>, accessed 3 September 2013.

${ }^{5}$ See L. Mulvey, Visual and Other Pleasures, $2^{\text {nd }}$ ed., New York, Palgrave Macmillan, 2009 and E. Ann Kaplan, Looking for the Other: Feminism, Film, and the Imperial Gaze, London, Routledge, 1997.

${ }^{6}$ R. Taylor, “A 'Cinema for the Millions': Soviet Socialist Realism and the Problem of Film Comedy,” Journal of Contemporary History Vol. 18, No. 3, July 1983, pp.439-61.

${ }^{7}$ K.Clark, The Soviet Novel: History as Ritual, 3d ed., Bloomington, Indiana University Press, 2000, p. 141. 84
} 
reality accessible to all was but a shadow of a "higher reality" of an ideal socialist society existing on the silver screen.

Nevertheless, it was scenes of Soviet everydayness that received musical and comedic treatment, whereas such foundational historical events as the Revolution and the Civil War were reserved for heroic drama (and sometimes also for the adventure genre targeting young adults). It would have been impossible to imagine a Soviet musical comedy about the storming of the Winter Palace or the defense of Tsaritsyn, for example. Indeed, the film director Gennadii Poloka's attempt in 1968 to turn the foreign intervention and the Bolshevik underground resistance in Odessa into an eccentric comedy resulted in the banning of that film, The Intervention. ${ }^{8}$

In order to understand the phenomenon of Wedding in Malinovka as a popular musical comedy about the Civil War, another important category needs to be introduced, that of national (or ethnic) cultural stereotypes. Scholars have noted the connection between imperial expansion and the development of ethnic stereotyping, which reinforced the power dynamics of the "imperial gaze."9 In the Eastern European context in particular, ethnic stereotyping often justified colonial domination as necessary familial guidance of a somewhat infantile junior sibling. As Myroslav Shkandrij has shown, there is a long tradition in Russian literature of portraying Ukrainians as a good-natured, lazy, humorous, and musical people living in a bucolic paradise. ${ }^{10}$ In addition to justifying the Russian political and cultural domination of Ukraine, such a stereotypical image also made it a convenient discursive site for treating serious issues in a burlesque or folkloric mode. If the Revolution in the RSFSR was a serious thing, one could find a setting for a light-hearted take on the Revolution in the south, in the Ukrainian SSR. Russian audiences were long accustomed to this representation of Ukraine as a land of countrybumpkins-funny “Little Russians," who loved singing and dancing, as well as that of shrewd-and also funny-J ews and Gypsies, the traditional yokels and villains of folk comedy. Regardless of whether one sees Ukraine as a true colony of Russia in political and economic respects, Marko Pavlyshyn and Myroslav Shkandrij have shown that the Russian-Ukrainian cultural interaction in modern times can be analysed productively as colonial and post-colonial relations. ${ }^{11}$ Thus, Wedding in Malinovka did the job perfectly by symbolically relocating the brutal Civil War far away from the Russian core, into the land of endless folk dances and recognizable stock characters. The film essentially normalised the Civil War by packaging it as an "ethnic" musical sitcom with dances.

The film thus continues the long line of works representing Ukraine in the burlesque stylistics of the so-called kotliarevshchyna, a term derived from the surname of the Ukrainian writer Ivan Kotliarevsky, who is remembered primarily for his low-style, humorous retelling of Virgil's The Aeneid (1798) that became the first published literary work in the modern Ukrainian language. If the burlesque framework was perhaps unavoidable in Kotliarevsky's time, in subsequent generations this way of representing things Ukrainian marked, in Marko Pavlysyhyn's words, self-deprecating "informality and the absence of claims to a place at the table of 'serious' culture."12 George G. Grabowicz has noted that, for all the subversive potential of kotliarevshchyna in relation to the empire's dominant Russian high culture, Russian critics long accepted it at face value as the only

\footnotetext{
${ }^{8}$ B. Beumers, A History of Russian Cinema, New York, Berg, 2009, p. 155.

${ }^{9}$ See R. Dyer, White: Essays on Race and Culture, London, Routledge, 1997; P. M. E. Lorcin, Imperial Identities: Stereotyping, Prejudice, and Race in Colonial Algeria, London, I. B. Taurus, 1999; E. Shohat and R. Stan, Unthinking Eurocentrism: Multiculturalism and the Media, London, Routledge, 1994.

${ }^{10}$ M. Shkandrij, Russia and Ukraine: Literature and the Discourse of Empire from Napoleonic to Postcolonial Times, Montreal, McGill-Queen's University Press, 2001, p. 81.

${ }^{11}$ M. Pavlyshyn, "Post-Colonial Features in Contemporary Ukrainian Culture,” Australian Slavonic and East European Studies Vol.6, 1992, pp. 41-55; Shkandrij, Russia and Ukraine op. cit.

${ }^{12}$ M. Pavlyshyn, Literatura, natsiia i modernist: Universytetski dialohy, No. 18, Lviv and Kyiv, Tsentr humanitarnykh doslidzhen; Smoloskyp, 2011, p. 15. See also Pavlyshyn’s pioneering article on the construction of the myth of Ukraine in Kotliarevsky: Marko Pavlyshyn, “The Rhetoric and Politics of Kotliarevsky's Eneida,” Journal of Ukrainian Studies, Vol. 10, No. 1, 1985, pp. 9-24. 
possible incarnation of Ukrainian culture. ${ }^{13}$ Burlesque, ethnographic Ukraine as a safe concept that did not threaten imperial hierarchies was carried over into the Soviet period, in particular after the conservative turn in Stalinist culture after the mid-1930s.

\section{The Quest for a Soviet Operetta}

The film Wedding in Malinovka was based on the eponymous Soviet operetta (1936) and set to a libretto by the Ukrainian-J ewish writer Leonid Yukhvid (1909-1968). The work thus came from a different background, that of musical-comedy or operetta theatre, in which the constant quest for "topical" Soviet operettas could conceivably result in a turn to a revolutionary topic. Because of the very nature of the musical-comedy genre, such a turn would not appear sacrilegious, the way it would have in Stalinist cinema. Furthermore, ethnic stereotypes and stock musical characterizations were also well entrenched in musical comedy. The artistic director of the Kharkiv Musical Comedy Theatre, Oleksii Riabov, wrote the music to Yukhvid's original Ukrainian text, and Wedding in Malynivka in its original incarnation as a Ukrainian-language operetta was briefly staged in Kyiv in 1938, but did not enjoy a long run. However, the work had a much longer run in Russia in a Russian translation with a new musical score by Boris Aleksandrov, which the Moscow Operetta Theatre first performed on 8 November 1937. It was this Russian version on which the 1967 film is based. It is also telling that the film was made at the Leningrad Film Studios rather than at the Dovzhenko Film Studio in Kyiv, even though all filming on location took place in Ukraine. Thus, this was an explicitly Russian cultural product about Ukraine.

Interestingly enough, it could have been a Ukrainian film. The archival collection of the Dovzhenko Studio contains a pre-production file on Wedding in Malinovka. These documents confirm that in the summer of 1960 Yukhvid signed a contract for a film script, which was duly delivered to the studio. However, the studio management procrastinated over assigning a director to work on the film, while at the same time demanding that the script be shortened. Finally, the contract was officially voided after two years, but Yukhvid kept his substantial honorarium by arguing that he fulfilled his obligations and it was the studio that lost interest in the project. ${ }^{14}$ The memoirs of the Russian actor Mikhail Pugovkin, who played one of the main characters in Wedding in Malinovka, confirm the existence of a "difficult story" behind the film, which was originally seen as a Dovzhenko Studio project. ${ }^{15}$ However, with the Revolution's fiftieth anniversary approaching, the management of the Ukrainian studio apparently turned down this project as "not serious," opting instead to mark the jubilee with historicalrevolutionary films. ${ }^{16}$ Significantly, though, a musical comedy about the revolution in Ukraine was not seen as inappropriate at the Leningrad Film Studio. In fact, the film reproduced the cultural tropes elaborated during an earlier, Stalinist period and as a part of an even longer Russian theatrical tradition.

The published memoirs of the famous Soviet operetta actor and director Grigorii Yaron shed an interesting light on how the traditional imperial stereotype of Ukrainians provided the makers of the new genre with a ready-made model. As artistic director since 1927 of the world's first state-funded operetta theatre in Moscow, Yaron was at the forefront of the search for a new Soviet musical comedy. The search was a difficult one. Party ideologists harshly criticised all attempts to combine topics from contemporary Soviet life with the conventions of Viennese operetta genre, including its stock characters and the celebration of gaiety. The state demanded a musical comedy that would be entertaining for audiences, but at the same time unmistakably "Soviet" in content, addressing significant social issues and providing an uplifting message about socialism. After several unsuccessful attempts to find a safe Soviet subject to laugh at, sometime in the mid-1930s word reached Yaron that

\footnotetext{
${ }^{13}$ H.Hrabovych [George G. Grabowicz], "Semantyka kotliarevshchyny,” in his Do istorii ukrainskoi literatury: Doslidzhennia, esei, polemika, Kyiv, Krytyka, 2003, pp. 291-305, here p. 302 and p.304.

${ }^{14}$ Tsedntralnyi derzhavnyi arkhiv-muzei literatury i mystetstva Ukrainy, f. 670, op. 1, spr. 1289, ark. 1-18.

${ }^{15}$ Mikhail Pugovkin, Eto bylo by smeshno...,Moscow, Rutena, 2000, p. 62.

${ }^{16}$ Vechernii Kharkov, 28 October 2012. 86
} 
Pressitch ANZJ ES 5(2)

a musical comedy based on Nikolai Gogol's Sorochyntsi Fair was running in Kharkiv with great success. Yaron felt that he was on the verge of finding a solution: "Gogol in operetta! Would this not be the key to a magic door that we could not open for so long? Would this not be the door to something our own, national, dear-our songs, our people, our beautiful nature?"17

What this meant in practice, however, was the recycling of the conventions of nineteenth-century provincial ethnographic theatre, a genre that imperial audiences could enjoy as a harmless portrayal of colourful minorities and which did not challenge fundamental colonial cultural hierarchies. When Yaron summoned to Moscow the Kharkiv librettists Yukhvid and M. Avakh, it turned out that their operetta "was based on Starytsky's Sorochyntsi Fair that had been staged by Ukrainian companies for many years." 18 Mykhailo Starytsky's 1883 comedy had a long stage history. Ukrainian (and some Gypsy) folk costumes, customs, and dances formed the core of its appeal to audiences in Russia, as well as in the empire's Ukrainian provinces. Characteristically, when Yaron decided to improve on the libretto, he read various nineteenth-century authors, whose work only reinforced the ethnic stereotype of the Little Russians as people who are not to be taken seriously. He names Vasily Narezhny (Vasyl Narizhny), Hryhorii Kvitka-Osnovianenko, and, amazingly, even Vissarion Belinsky, whose most significant contribution to nineteenth-century debates about Ukrainian culture consisted of openly denying its right to exist. ${ }^{19}$

After the success of Sorochyntsi Fair with Russian audiences, Yaron wanted to apply his newly discovered recipe to other, perhaps more topical, projects. He acknowledged later that Wedding in Malinovka "in some way became the continuation of what we found while working on Sorochyntsi Fair."20 In the summer of 1936 Yukhvid arrived from Kharkiv with the first draft of a comedy about the Civil War in Ukraine that would become Wedding in Malinovka. Yaron felt that the play was "new and unusual for operetta theatre and at the same time had all that the latter required: an uplifting character, romanticism, colourful content, and gaiety, as well as the possibility to show folk dances and songs, in which the protagonists could pour out their sorrow, joy, and daring." 21 The Moscow Operetta Theatre hurriedly embarked on staging Wedding in Malinovka in time for the Revolution's twentieth anniversary in November 1937.

Of course, what Yaron called "folk songs and dances" was really a modern imitation of such or even explicitly new musical material, including certain folk-song elements. In part this was connected to the composer and script-writers' desire to collect their royalties for the "original" score, but it was also a way to insert a "Soviet" component into the work in the form of dialogue or musical citations from revolutionary songs. Although Yukhvid had originally worked with the Ukrainian operetta composer Oleksii Riabov, in Moscow a new musical score had been commissioned from the Russian composer Boris Aleksandrov, who had close connections to the Red Army Choir. This change was likely just a formality, however, because the lead song was exactly the same in the Ukrainian and Russian versions, and it is difficult to imagine more than one way of setting it to music. Imitating the dancing rhythm and vocabulary of Ukrainian folk songs, the song went, "A girl was seeing off the Cossack to the Kotovsky army / She stood by the road, beautiful as a guelder rose (kalyna)."22

\footnotetext{
${ }^{17}$ G. Yaron, O liubimom zhanre, Moscow, Iskusstvo, 1960, p. 178.

${ }^{18}$ Ibid.

${ }^{19}$ Ibid. On Belinsky’s dismissal of modern "high” Ukrainian culture, see Andrea Rutherford, "Vissarion Belinskii and the Ukrainian National Question,” Russian Review Vol. 54, No. 4, 1995, pp.500-15.

${ }^{20}$ Yaron, O liubimom zhanre, p. 178.

21 Ibid.

${ }^{22}$ Grigory Kotovsky (1881-1925) was a Red cavalry commander during the Civil War who was posthumously mythologised as a popular hero of the Revolution in the south. His guerrilla detachment (later cavalry brigade and division) operated in southern Ukraine in 1919-20.

87
} 


\section{The Civil War as an Ethnic Sitcom}

Like the operetta, the film is set in 1920 in the southern Ukrainian village of Malynivka (Rus., Malinovka), which had changed hands so many times during the Civil War that the locals were never sure under what regime they were living on any given day. Indeed, in the film's opening line, a Red cavalryman is asking a villager, "Under what government is your Malinovka today?” We are immediately introduced to Mayor Nechipor and the young lovers Andreika and Irinka, who are all expecting the Reds to arrive, and the kulak Baliasnyi. The Reds are indeed in the vicinity, but the first to enter the village is the independent band of the native son Hrytsko, who now calls himself Lord Otaman Gritsian of Taurida. Naturally, he is the son of the kulak Baliasnyi and he too is in love with Irinka, whom he wants to marry. The Red commander Nazar Duma makes it into the village disguised as the White liaison officer the gang is expecting, and the Reds launch their attack during a wedding. Of course, Nazar also turns out to be Irinka's long-lost father, a revolutionary who had been imprisoned in Siberia.

The process of translation inevitably changed the comedic accents of the work because so many of them relied on language-switching. In the Ukrainian original, most characters speak literary Ukrainian, but some also mix Ukrainian and Russian in a way typical of so-called surzhyk. ${ }^{23}$ This comedic effect is completely lost in the Russian translation and, in fact, replaced with a more sinister one, in which Ukrainian phrases are spoken by negative characters. The main villain, Otaman Gritsian, switches to Ukrainian twice in the play. The first time is when he proclaims his intention to establish an independent state (samostiinu derzhavu) in Malynivka County, and the second is when he demands money for his band from his kulak father (Hroshi, batku, hroshi!). Although the main positive protagonist, the Red commander Nazar Duma, is a local Ukrainian, he uses this language only once in the film. Tellingly, this happens when he is working undercover pretending to be a White officer, who in turn pretends to be a soldier returning from the front. This situation of double deceit already marks his linguistic choice as "fake," not to mention that the phrase itself is inappropriately low-culture, out of step with his usual conduct: "Ta ty sho, skazyvsia?” (Have you gone crazy?).

Perhaps even more tellingly, Gritsian is visually connected in the film to Ukrainian history in a way no other character is. In Yukhvid's play, he is only described as "all decorated with bombs and revolvers, with rings on his fingers." 24 However, in his first appearance in the film he wears the historical Cossack costume complete with baggy pantaloons, a blue waist sash, jerkin, sheepskin hat, and a saber. In the second part of the movie, when Gritsian is dressed up for his wedding, he keeps the pantaloons and the sash, which he wears with a tailcoat over a formal shirt-a symbolic combination of "bourgeois" dress with the historic Ukrainian one.

If the Ukrainian setting of the story was resignified by the Russian translation and the strengthening of negative accents, the overall ethnic landscape of the play also merits closer attention, not least because of its omissions. Leonid Yukhvid was born in the southern Ukrainian town of Huliai-Pole, which served as the capital of Nestor Makhno's anarchist republic during the Civil War. As a J ewish boy growing up in the midst of a violent military conflict that included bloody J ewish pogroms, it is curious that he did not include a single J ewish character in his play. In my view, however, a symbolic displacement took place here, a displacement that contemporary audiences "read" easily. The negative character who is given most prominence in the play, the Russian-speaking Odessan Greek Popandopulo, is a thinly disguised J ewish yokel. ${ }^{25}$ Historically, this comic character was a role reserved for J ewish actors who spoke with the "Odessan” accent. The first Popandopulo was Grigory Yaron himself, the leading character actor of early Soviet operettas. In the film, the role of

\footnotetext{
${ }^{23}$ On surzhyk, see Laada Bilaniuk, Contested Tongues: Language Politics and Cultural Correction in Ukraine, Ithaca, N.Y., Cornell University Press, 2006.

${ }^{24}$ L. Yukhvid, "Vesillia v Malynivtsi,” Sotsialistychna kul'tura, No. 5, 1939, p.56.

${ }^{25}$ Popandopulo’s “implicit Jewishness” has been noted by other scholars. See, e.g., Jarrod Tanny, City of Rogues and Schnorrers: Russia's Jews and the Myth of Old Odessa, Bloomington, Indiana University Press, 2011, p. 151. 88
} 
Popandopulo is played by the equally famous Mikhail Vodianoi (Wasserman), who would eventually become the director of the Odessa Musical Comedy Theatre.

Regardless of his Greek name and the historical presence of ethnic Greeks in southern Ukraine, Popandopulo functions in the film as a crypto-J ew because traditional Ukrainian and Russian popular cultures did not possess an established stereotype of a Greek, and there was no such character in folk tales or puppet theatre. Instead, Popandopulo clearly takes over the role traditionally reserved for a J ew and gets a beating in exactly the same way the "J ew" would in the historical vertep puppet theatre.

Popandopulo is encoded as un-manlike in the film. He is dressed in a striped sailor's jersey that is much too small for him and red hussar trousers that he obtained from some speculators by trading the gang's machine-gun for them. He swings his hips when he walks. At a wedding he sings in a woman's voice (lip-syncing to a gramophone record), "Caress me, be bolder with me, the devil take you." He cannot take a strong handshake and is constantly beaten up by both men and women, his only reaction to this being to complain of his "nerves" and to ask bystanders why they did not defend him. Finally, Popandopulo is the first to abandon Gritsian and run away (naturally, dressed as a peasant woman carrying a goose). His favourite expression of admiration in the film is "Why, but why am I so much in love with you?" and it is always addressed to men.

If such gender characterization makes Popandopulo a weak enemy, his speech patterns and singing also make him a lovable weak enemy. In both the Ukrainian and the Russian versions of the operetta he speaks the endearing Odessan Russian filled with criminal slang and funny expressions. He also sings politically unsound songs; the one about a certain Marusia in pink stockings became an instant hit with Soviet audiences. Explicitly apolitical, sexual, and suggestive of the narrator's identity as a thief, this song imitated the non-Bolshevik mass culture of late imperial Russia and the 1920s.

According to the Soviet musical critic Elizaveta Grosheva, Vodianoi's Popandopulo possesses a "naive, almost childlike vulnerability, even kindness-precisely the features causing the audiences to smile and sympathise with him."26

If the "implicit J ew" Popandopulo is central to the film's plot, just as he was in the original Ukrainian text, a close reading of the latter also reveals another "hidden"

ethnic character in the film. The play features two protagonists with Moldovan names, who introduce themselves as natives of Bessarabia: Petria, the Reds' second-in-command, and Yashka, a soldier and jokester, whose speech and his sister's name suggest Gypsy origins. In the film, these two roles are merged into one, that of Petria, but he is played by the most recognizable Soviet Roma actor and singer, Nikolai Slichenko. His portrayal of Petria is characterised by heightened emotionality, lyrical singing, and dancing with reckless abandon. At the end of the film, when all the main protagonists kiss their opposite-sex partners with whom they have been reunited, Petria kisses his horse. This is, of course, a not-so-subtle reference to the folkloric stereotype of the Gypsy as a horse thief.

\section{The Dancing Conquest of Ukraine}

If J ews and Gypsies are implicitly present in the film and not just through the assignment of their roles to famous actors of the same ethnicity, it is significant that the most memorable Ukrainian character is played by a Russian actor, Mikhail Pugovkin. His role (Yasha the soldier) differs somewhat from the Ukrainian libretto, in which Yashka the Bessarabian is sent undercover to Malinovka by the Reds. In the film, Yasha the soldier is a stranger making his way home from Austrian captivity, but stopping in Malinovka because his own village nearby has been burned down by the Whites. As Yaron explained in his memoirs, this difference between the Ukrainian and Russian libretti emerged during the production stage in 1937, when the Moscow Operetta Theatre was rushing to stage Wedding in Malinovka in time for the Revolution's anniversary. Since Yukhvid was allegedly slow in sending the requested revisions, Yaron assigned the task to the Moscow dramaturge and Odessa native Viktor

\footnotetext{
${ }^{26}$ Quoted in V. S. Maksimenko, Imia: Mikhail Vodianoi, Odesa, OKFA, 1999, p. 87.
} 
Tipot (as in "tea pot"; real name: Ginzburg). ${ }^{27}$ As a result, one of the play's central characters, who in Ukraine was portrayed as the Red officer working undercover and thus pretending to be a funny simpleton, in the Russian version becamejust an amusing Ukrainian yokel. This symbolic detachment from the Reds allowed the character of Yasha to become one of the two principal clowns in the film rivaling only Popandopulo. His endless jokes, misplaced German words, and dancing are among the movie's main attractions. Particularly interesting is the scene in which he tells a local peasant woman that (the traditional Ukrainian dance) hopak is now "out of fashion," and he proceeds to teach her to dance what he believes is the fashionable European "two step." However, he pronounces it as $v$ tu step" ("into this steppe"). Their awkward dancing to foxtrot-like music in a yard behind the hut both lampoons Western mass culture of the 1910s and, by extension, presents Ukraine as backward and not suited for anything but folk singing and dancing.

Although he joins the Reds in the end, Yashka the soldier is in fact an archetypal "Little Russian" jester of the Russian popular theatre. In the tradition of the famous Shelmenko (a Ukrainian jester character in the nineteenth-century plays of Hryhorii Kvitka-Osnovianenko), he is looking for a job "that would not involve much work, for example as a boss of some kind." In the meantime, he occupies himself with practical jokes, dancing, and singing. Pugovkin's portrayal of a funny "Little Russian" was so successful that in 1971 he played Shelmenko in the Russian film Shelmenko the Orderly, also directed by Tutyshkin. Significantly, the actor himself felt that he was not qualified for the role because he did not know any Ukrainian, but the director did not see this as an impediment. ${ }^{28}$ His brand of "Little Russian" comedy did not require any cultural authenticity in the depiction of Ukrainians, but rather the consistent application of the "imperial gaze."

If it is easy to see in the film the tropes and narrative models borrowed from nineteenth-century Ukrainian ethnographic theatre and colonial comedic stereotypes, establishing its relationship to earlier Soviet films about the Civil War is considerably more difficult. There is an obvious intertextual reference to perhaps the most famous of them all, Chapayev (1934), in the form of a circle-top window through which a Red soldier conducts reconnaissance at Gritsian's camp. It is almost exactly the same window through which Chapaev fires his machine gun at the advancing Whites. Yet, in many respects, Wedding in Malinovka is Chapayev in reverse. Instead of the Whites storming the Red camp during the night, it is the Reds who surprise Gritsian's drunken fighters with a night-time raid. Instead of Chapayev's soldiers (and Chapayev himself) representing the "people" that Commissar Furmanov needs to indoctrinate with communist consciousness, the Reds in Wedding in Malinovka are shown as unambiguously pro-Soviet. ${ }^{29}$ It is the local Ukrainians who are divided in their loyalties, a situation that frames the plot as a story of liberation and punishment by the Bolsheviks, essentially just another way of narrating the conquest. The liberation aspect is represented symbolically by the film's longest dance scene, in which uniformed Red soldiers whirl dozens of Ukrainian young women dressed in traditional embroidered costumes in a dance fusing elements of Ukrainian, Russian, and Red Army dance steps.

Yet, the dancing conquest of Ukraine remains tantalizingly incomplete because by the end of the film it is unclear to the viewer what has happened to Gritsian, who is last shown running away. The fate of his father, the kulak Baliasny, is not apparent either. In Yukhvid's Ukrainian original, a Red soldier says that they have lost track of Baliasny, an obvious reference to Stalinist official discourse postulating that alleged kulak saboteurs were still operating throughout the Soviet state, and in Ukraine in particular. The symbolic capture of the enemy in the film is limited to a comedic apprehension of the crossdressing Popandopulo. ${ }^{30}$ However, the most subversive, if unintentional, element of the film's finale

\footnotetext{
${ }^{27}$ Yaron, O liubimom zhanre, p. 182.

${ }^{28}$ Pugovkin, Vse eto bylo by smeshno, p. 66.

${ }^{29}$ On Chapayev, see Julian Graffy, Chapaev: The Film Companion, London, I. B. Taurus, 2010.

${ }^{30}$ In the short-lived sequel operetta Second Wedding in Malinovka that was staged in Odessa in the 1970s, the audiences met Popandopulo again after he had served twenty years of hard labor (Maksimenko, Imia: Mikhail Vodianoi, p. 87). This 90
} 
could actually be Yashka the soldier volunteering to join the Red Army. If he is to be seen as the Shelmenko of the Civil War period, then who would be the subject of his pranks? As Grabowicz and Pavlyshyn have shown, the character of Shelmenko and, more generally, the burlesque element of kotliarevshchyna exist (and can only exist) in an ambiguous symbiosis with the imperial master culture. Kotliarevshchyna does not challenge the prevailing order directly, but thrives on satiricizing its elements. It also served historically as an expression of cultural difference, even if it portrayed an allegedly subordinate, lower-class ethnic culture in relation to the dominant imperial one. ${ }^{31}$ In other words, Yashka-Shelmenko was probably going to be more of a problem than an asset for the Red Army - and a challenge to any form of homogenous "Soviet" identity.

There was a good reason why Wedding in Malinovka was much more successful in its Russian version. By playing on traditional cultural stereotypes, it presented the Civil War as an ethnic affair, and a funny one at that. Soviet Russian audiences welcomed such a version of the Civil War, in part because it helped them rewrite their own difficult past as a colonial operetta. However, if the operetta and the film remain popular in post-Soviet Russia, where the traditional image of Ukrainians is alive and well, it has been spared a political reaction in post-Soviet Ukraine. Yet, as is the case with so many colonial cultural models, the ethnic stereotypes employed in Wedding in Malinovka are deeply ambiguous. By turning tricksters into allies and sympathetic jesters into enemies, the burlesque representation of colonial subjects undermined the intended imperial triumph of the film's finale.

new development in the story line provided a closure of sorts for the original work's plot, but did not necessarily remove the ambiguity and audience sympathies associated with this character.

${ }^{31}$ Hrabovych, “Semantyka kotliarevshchyny,”p. 298; Pavlyshyn, Literatura, natsiia i modernist, p. 26. 